\title{
Picturing (as) Resistance: Studying Resistance and Well-Being of Indigenous Girls and Young Women in Addressing Sexual Violence
}

\author{
Claudia Mitchell and Maria Ezcurra
}

\begin{abstract}
The health and well-being of young people remains a critical issue. For Indigenous girls and young women in Canada and South Africa, the situation is exacerbated by high rates of sexual violence. The article draws on examples of artworks and close readings of several images of resistance produced by Indigenous girls and young women participating in a six-year study that seeks to address sexual violence in the two countries. Exploring resistance is an understudied area in relation to young people and well-being. Building on our visual research and fieldwork, we posit that the idea of "picturing (as) resistance" through the various participatory visual and arts-based tools is a promising area of investigation in relation to wellbeing.
\end{abstract}

\section{Picturing (as) Resistance: Studying Resistance and Well-Being of Indigenous Girls and Young Women in Addressing Sexual Violence}

\author{
"What would it really mean to study the world from the standpoint of adolescence both as \\ knowers and as actors?" Ann Oakley (1994, p. 23).
}

Oakley's question is an important one for framing and reframing research to take account of the perspectives of young people in matters that are of importance to them. Her question is a particularly relevant one in the context of mental health and well-being. We know that one in five young people has mental health issues, and that matters of age, gender, race, class, disability, sexuality, and cultural and historical contexts are all pertinent (Crivello, Camfield, \& Woodhead, 2009). For example, according to the Native Women's Association of Canada, ${ }^{1}$ Canadian Indigenous girls are three times more likely than non-Indigenous girls to experience violence. Oakley's question provides the foundation for a six-year study working with Indigenous girls and young women in two country contexts, Canada and South Africa. In the project, as we explore in this article, Indigenous girls and young women from school and community sites across the two countries have been engaged in participatory arts-based approaches to addressing sexual violence. A question that is particularly pertinent as the project evolves is the idea of health and well-being itself and the ways in which engagement and empowerment could contribute to strengthening well-being. Considering the investment of time of the participants and the very sensitive nature of the workshops, we want to question in an explicit way what we are learning about well-being in the context of participatory approaches to addressing sexual violence, and how participatory visual research might contribute to deepening an understanding of youth participation and well-being more broadly. What 
frameworks are appropriate for exploring young people's participation in relation to well-being? What are some of the implications for school-based and community programs? We position the article as one of "picturing resistance" as a way to improve the perception of what well-being could look like for girls and young women in two country contexts where, as we explore below, the situation for Indigenous girls and young women in relation to sexual violence is similar. Our article is conceptual in orientation and, as such, seeks to deepen an understanding of what the image-making experience and the images themselves might mean in the context of well-being.

\section{Learning Across Countries}

We start by looking at some of the contextual factors for learning across the two country contexts. There are dramatic contradictions between the constitutional and legal frameworks and the everyday realities for marginalized populations of girls and young women. In many ways, Canada and South Africa have a shared history in relation to racialized colonization and segregation, something that is evident in the treatment of Indigenous populations in Canada, and in the effects of apartheid in South Africa. While the governments of Canada and South Africa have attempted to confront past injustices through the establishment of Truth and Reconciliation Commissions, ${ }^{2}$ both countries have continued to come under scrutiny by international organizations such as Human Rights Watch ${ }^{3}$ and the United Nations ${ }^{4}$ for their failure to create safe and secure environments for girls and young women.

With the launch of an Independent National Inquiry into Missing and Murdered Indigenous Women and Girls (MMIWG) in 2016, the Canadian government has committed to examining the systemic causes of all forms of violence against Indigenous women and girls in Canada and to finding ways of preventing violence. According to the National Inquiry into Missing and Murdered Indigenous Women and Girls website, ${ }^{5}$ Indigenous women and girls face the highest poverty and violence rates in Canada, where hundreds have gone missing or have been murdered during the last 30 years. The National Inquiry into Missing and Murdered Indigenous Women and Girls affirms that it has given its commissioners the authority to conduct the National Inquiry autonomously, acknowledging the emotional well-being of those who have lost a daughter, sister, or mother. As a Globe and Mail article highlights, to acknowledge and honour the lives of the hundreds of missing and murdered Indigenous women and girls in Canada, the judicial system must implement immediate actions, considering the well-being of the Indigenous women and girls and their families and communities (Eaglewoman, 2016).

There is a big difference between the social and economic well-being of non-Indigenous populations and Indigenous communities, whose conditions are compared to those in developing countries (Carli, 2012). Colonization had a negative impact on the well-being of Indigenous communities in Canada, affecting

principally Indigenous women, who face gendered racism, sexism, poverty, single motherhood, a lack of educational achievement and employment opportunities. The gender-based violence many Indigenous women experience in their homes, their communities, and Canada in general, has had an impact on their cultural identities and influenced also their access to health and personal well-being (Bourassa, McKayMcNabb, \& Hampton, 2004; Halseth, 2013). These forms of violence can also be linked to the legacy of 
the residential school system. Many Indigenous women endure the prolongation of a structure in which abuse and violence are the "norm," lacking the necessary support from the justice system, male chiefs and council members, and society at large (Halseth, 2013).

South Africa, for its part, launched the National Council Against Gender Based Violence to respond to the dire situation for girls. ${ }^{6}$ South Africa has one of the highest rates of sexual assault in the world, and while absolute numbers are unreliable because of underreporting, adolescent girls between the ages of 12 and 17 are particularly at risk. As Banwari (2011) notes, in 2000, of the over 52,550 cases of rape or attempted rape of girls and women reported to the South African Police Service, 21,438 were under the age of 18 years (with 7,898 of these under 12 years). Confounding the underreporting of sexual assault is the fact that rates of prosecution are low; a 2005 study indicates that fewer than $1 \%$ of cases actually result in a conviction. There is a consistent (and unrelenting) possibility of sexual violence that runs counter to girls' safety and security in schools and communities, and to their reproductive health, particularly in the context of HIV and AIDS (Moletsane, Mitchell, \& Lewin, 2015). While South Africa has made major strides in enrolling girls in primary education, one of the most pervasive reasons for the poor participation and low success of girls in the schooling system is gender inequality, and, in particular, its manifestations of violence against girls and women, and related health issues (most notably HIV infections and compromised reproductive health). In the case of rural South Africa, poverty, traditional leadership, geographic isolation, and legal and cultural frameworks intersect in the regulation of the lives of girls and women. Moletsane (2011) highlights the idea that, "so-called cultural practices" (p. 89), particularly in

relation to performing sexualities, typically intersect in ways that place girls as the lowest of the low as far as having control over their bodies is concerned and this is further complicated by the high and gendered incidence of HIV and AIDS. Motsemme (2007) comments on the effects of the physical uprooting that characterizes the lives of rural and township girls and notes that, "uprootedness as a form of physical and spiritual violence is an aspect which surprisingly continues to receive scant attention in South African social studies" (p. 373).

\section{Young People, Mental Health and Well-Being and Arts-Based Interventions: A Brief Overview}

Looking at the situation for Indigenous girls and young women, we see the idea of well-being as a critical one. We acknowledge the broad range of mental health and well-being concerns experienced by young people, ranging from substance abuse, eating disorders, bullying, sexual identity, and issues of migration, to name only some, as stated in The Chief Public Health Officer's Report on the State of Public Health in Canada, 2011. We also acknowledge the challenges for educators and health professionals to find solutions to problems that seldom exist as single issues as we see in the critical work in the area of resilience (Theron, Liebenberg, \& Ungar, 2015) and flourishing (Seligman, 2011). We situate our work on the growing body of participatory research with young people related to issues of heath as we see in the studies by Brown, Shoveller, Chabot, and LaMontagne (2013) and Didkowsky, Ungar, and Liebenberg (2010) on risk health and well-being. The participatory visual work of MacDonald et al. (2015) on resilience in work with Indigenous youth in Rigolet, and Flicker et al. (in press; 2013) with Indigenous 
young people has taken on a "stay native and stay healthy" approach that also helps to frame how might we look at participatory visual research in relation to the health and well-being of young people, and in particular, what it might mean for young people's actual participation.

Aside from these studies there are, to date, few studies within participatory visual research with young people that explore issues of well-being even though there is often an implicit sense that notions of participation and working with the visual through media production are inherently good (for the participants). Terms such as "voice," "agency," and "empowerment" are used in relation to participatory visual work (see Clover, 2011; Crivello et al. 2009; MacDonald et al., 2015; Mand, 2012; Moletsane, Mitchell, \& Lewin, 2010; Moletsane et al., 2015), and there is an increasing recognition that young people are by themselves choosing to represent their perspectives on such critical social matters as feminism, violence, and environmental issues. Some of this work can be seen in youth-led social movements, such as Idle No More amongst Indigenous young people in a Canadian context, while other examples, as Caron, Raby, Mitchell, Théwissen-Leblanc, and Prioletta, (2016) highlight, can be found in the work of individual youth whose productions reach many other young people through 'social change oriented' vlogs and other forms of social media.

An important area of inquiry that draws together much of the participatory work with young people concerns the ways in which youth-focused methods can be decolonizing in and of themselves through the use of participatory digital and other arts-based methods. Participatory interventions are typically part of community-based research, drawing on audio, visual, and performance-based research methods, such as Gonick's (2016) work in film with Inuit girls in Iqaluit; Flicker and Danforth's (2012) work with digital storytelling with Indigenous youth; Liebenberg's (2009a) work with participatory video with Indigenous youth in Happy Valley, Goose Bay; De Lange, Mitchell, and Moletsane's (2015) work with rural South African girls and the use of cellphilms; Mitchell's work with drawing and mapping involving girls in Kenya and Rwanda, and the extensive work with youth in the area of PhotoVoice in Ethiopia, Swaziland, and South Africa (Mitchell, 2009, 2011a, 2011b, 2012; Moletsane et al., 2007), all point to the ways in which these various narrative modes build on storytelling conventions of communities and, as such, have the potential to both subvert some of the researcher-researched power dimensions, and contribute to a milieu where the perspectives of young people are recognized.

The idea of participatory interventions to address critical social justice issues, such as violence prevention, is framed within a rich body of work housed in research areas such as community based research, media and participatory cultures research, and participatory visual methodologies studies. Applied to youth, this work typically draws on visual and performance-based research methods such as PhotoVoice, participatory video, drawing and map making, digital storytelling, theatre performance, radio production, podcasts, and collage (see Clacherty, 2005; Denov, Doucet, \& Kamara, 2012; Gubrium, 2009; Liebenberg, 2009a, 2009b; Malone, 2008; Mitchell, 2011a, 2011b; Moletsane, Mitchell, Smith, \& Chisholm, 2008). This use of digital and social media in this work has looked at the ways in which young people themselves are "knowledge producers" (Stuart \& Mitchell, 2013) in relation to issues that are critical to their everyday 
lives (Bloustien, 2003; Buckingham, 2003, 2007; Carrington \& Robinson, 2009; De Castell \& Jenson, 2003; Jenkins, 2006; Mallan, 2009; Morrison, 2010; Poletti, 2008).

Following from the work of Buckingham and Sefton-Green (1994), the focus of this research is typically on youth producing the messages that come out of their own experiences, but which then become the "entry point" for further work in terms of critique and taking action. As Leach and Mitchell highlight in their 2006 book, Combating Gender Violence In and Around Schools, interventions that are particularly promising are those that draw on the engagement of young people themselves. Mitchell, Walsh, and Moletsane (2006), for example, describe a number of arts-based interventions where young people draw, work with photos, or produce videos that document their everyday realities. In more recent studies, Mitchell (2011a, 2011b) highlights work with participatory video with youth in rural KwaZulu-Natal and the various ways in which the resulting videos produced by young people can be used. First, they serve as graphic local evidence of gender violence. Second, they also serve as pedagogical tools for discussion and, as such, are part of an intervention in and of themselves (Mitchell, 2012).

\section{Studying Resistance and Well-Being Through the Arts}

In proposing the idea of connecting resistance and activism to well-being in working with girls and young women to address sexual violence, we have been inspired by powerful examples of the ways in which artistic expression and media-making at a national level in both Canada and South Africa are contributing to advocacy on addressing issues of social justice. There are several examples of community art projects that function as a healing agent during difficult times. ${ }^{8}$ These projects can change the way in which the artists, the participants, or the community perceive their reality and relate to it within their context, improving their wellness. More than a decade ago Marilyn Martin (2003) asked the question, "HIV/AIDS in South Africa: Can the Visual Arts Make a Difference?" Her question was a critical one in relation to highlighting the ways in which art can both inspire, as well as contribute to, a collective sense of working together. Creative processes are recognized as an innovative approach to increase health and well-being. In Canada, there is a strong connection between cultural participation and health and well-being (Hill, 2013). Women and other groups of people who have been historically marginalized seem to feel more benefited from participating in art processes (Tepper et al., 2014). Numerous Indigenous women artists in Canada use traditional native crafts to emphasize unresolved problems of social justice and to dispel stereotypical notions about Indigenous people. See, for example, Winnipeg's Métis artist Jaime Black, who created The REDress Project, ${ }^{9}$ an ongoing installation through which she reflects on the gendered and racialized nature of violent crimes against Indigenous women. Made from dozens of red dresses collected from the community and hung in public spaces, this piece is a visual reminder of the nearly 1,200 Indigenous women who have been murdered or gone missing over the last 30 years in Canada. Walking With Our Sisters ${ }^{10}$ is a travelling installation made of almost 2,000 moccasin vamps. Participants are invited to walk barefoot on a path of cloth alongside the vamps, to remember and honour missing and murdered Indigenous women and girls. Another meaningful Indigenous project is The Faceless Dolls Project, ${ }^{11}$ an initiative of The Native Women's Association of Canada that uses dolls to bring attention to the issue of murdered and missing Indigenous women. Through workshops facilitated by artist Gloria 
Larocque, participants created visual representations of 582 documented cases of missing and murdered Indigenous women and girls in Canada, embodying the alarming dimension of this problem.

In South Africa, where the rate of gender-based violence is among the highest in the world, there are many powerful examples of art that has been done by women to explore, share, and resist histories of sexual violence. Dirty Laundry, ${ }^{12}$ an installation by South African artists Nondumiso Msimanga and Jenny Nijenhuis_-both sexual assault survivors_-displays 3,600 pairs of used female underwear (the number of rapes happening in South Africa every day). The underwear, donated by other survivors of sexual violence to share their stories and create awareness on this issue, hung on a 1.2-km-long washing line suspended above the streets of Johannesburg. Loslappies ${ }^{13}$ is a project that looks at how women's bodies and sexuality are described in ways that perpetuate and normalize violence. Embroidering on underwear, the collective Boitumelo, in collaboration with Erica Lüttich, present words in multiple South African languages that refer to women with derogatory connotations.

These are just a few but powerful examples of how resistance through the arts in relation to everyday acts can destabilize social norms, contributing to positive changes and rejecting oppressive social structures, relations, and identities. Another good example of creating awareness and promoting resistance through art is Maria Ezcurra's The Threads, Trends and Threats of the Wedding Dress (2016), a participatory research-creation work that explores notions of romantic love and how it affects women's identities and relationships. Wedding dresses were collaboratively transformed to explore, represent, and resist the perpetuation of normative femininity and normalization of violence against women behind Western wedding imagery (White, 2015).
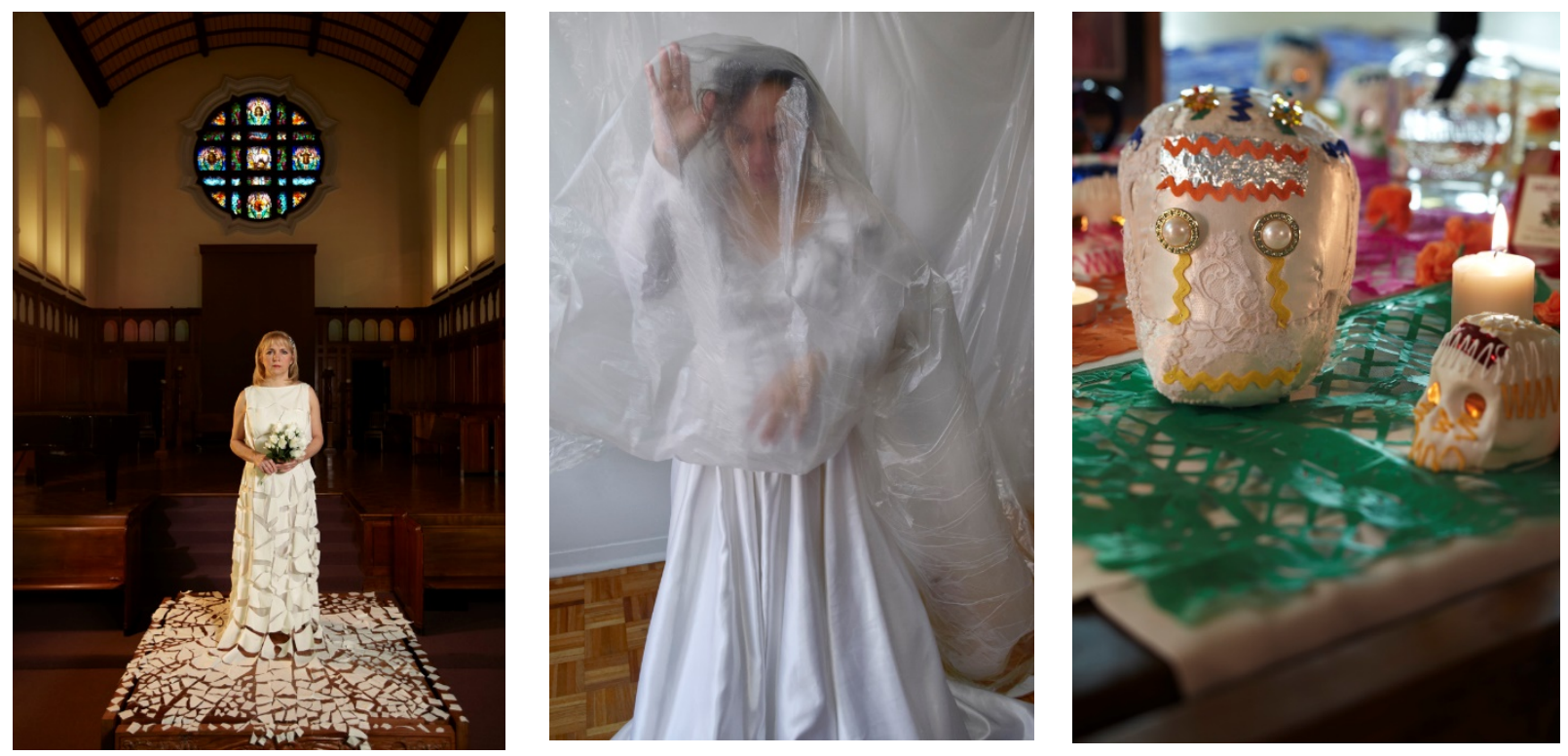

Fig. 1, Fig. 2., and Fig. 3: Anne, Flavia and Des (2016). Part of the series The Threads, Trends and Threats of the Wedding Dress, by Maria Ezcurra in collaboration with the participants.

It is quite significant that most of the women artists mentioned above incorporate garments in their work to address gendered-based violence. Dress, as an important aspect of material culture, is continually 
mediating between the body and the world, participating in the construction of gender stereotypes that affect women's beliefs and social practices (Crane, 2000). However, actively transformed into art, clothing (and the body) has the capacity of disrupting or resisting heteronormative operations of power. Based on both the personal and social implications of dress, many artists use it in their work to resist social rules and taboos (Teunissen, 2009). Agency and performativity are significant elements of these artworks, influencing the form in which gendered bodies are socially produced and individually signified.

What is clear in these arts-based projects is that many girls and women, both within Indigenous communities and beyond, are shaping and reshaping familiar situations as forms of resistance against oppressive systems that intend to restrict them. The arts and other visual explorations are commonly used to share the experiences of oppressed groups and question their circumstances, understanding creativity not only as a site of resistance, but also as an opportunity for learning and enjoyment. Historically, diverse groups of girls and women have used the arts and crafts as a form of resistance to critical issues that affect and restrict their lives, allowing them to become active agents of change (Clover, 2005, 2011). Today, new technologies and media, such as cellphilming, participatory video, community radio production, podcasts, digital collage, drawing, map making, and storytelling, are also becoming imaginative and innovative practices used by women, youth, and Indigenous communities to educate, empower, resist and demand justice. Resistance not only works as a symbolic opposition to restrictive norms, but also as a way to positively change environments with the participants' attempts to eliminate oppressive societal structures and identities.

\section{Picturing Resistance: Studying Participant-Produced Images}

In this section, we consider the images produced by Indigenous girls and young women in Canada and South Africa in the context of Networks for Change and Well-being: Girl-led 'From the Ground-Up' Policy Making to Address Sexual Violence in Canada and South Africa, a six-year study involving girls and young women between the ages of 14 and 24, meeting in eight field sites in the two countries. Through a range of arts-based visual approaches such as cellphilming, PhotoVoice, and digital storytelling carried out through community and school-based workshops, the participants have been engaged in identifying what they see as the key challenges and solutions to sexual violence.

The broad objectives for the study include the following:

1. To build knowledge and understanding from disciplinary, interdisciplinary, and/or cross-sectoral perspectives on sexual violence through support for leading researchers in both Canada and South Africa;

2. To build the capacity of girl-focused community structures to combat sexual violence;

3. To deepen an understanding of Indigenous knowledge (in relation to methodologies, ethics, and well-being) in the context of a transnational study of Indigenous girlhoods;

4. To advance the application of digital and social media tools in participatory research, and the development of innovations in communication networks in addressing sexual violence; 
5. To study the impact of participatory policy-making in relation to sexual violence in local, national, and international communities;

6. To create a transnational platform for raising awareness and advocacy on sexual violence.

To date, we have written about some of the methodological issues in the study - the "how" of participatory visual engagement in addressing sexual violence (De Lange, Moletsane, \& Mitchell, 2015), policy dialogue (De Lange, Mitchell, \& Moletsane, 2015), ethical challenges in carrying out participatory visual research (Treffry-Goatley, Wiebesiek, \& Moletsane, 2016; Treffry-Goatley, Wiebesiek, Moletsane, \& De Lange, forthcoming), and the idea of the engagement of girls and young women in political activism (Mitchell, De Lange, \& Moletsane, in press a). How to look at activism and how to read activism in the context of well-being offers, we think, another way to think about the images being produced by the participants. Building on the idea of working with visual images as highlighted in the section above, what can we learn about well-being?

In analyzing the collection of images, some of which also include captions, we have been interested in how resistance has been represented across the various field sites. We acknowledge that resistance is itself a term that is open to interpretation, and that as Kovach (2009) observes, it is critical to recognize that Indigenous inquiry in itself is as type of "resistance research" (p. 18). Some of the representations in the data set have been explicitly about resistance as we see in a poster produced by a group of Indigenous girls and young women in Eastern Canada. The poster carries the caption "Resisting Sexual Violence" (Networks4Change, 2017, p. 16). Others take up the issue of resistance through the images themselves as in an image of a body gesture such as a hand pushing back.

As a way to explore the images and how they might inform the idea of picturing resistance, we draw on the work of Gillian Rose (2012). Rose in her framework for visual analysis talks about three sites: the image itself as a site, the site of production (which would refer to the producers themselves), and the site of audiencing (and how audiences view/experience the images). While as both Rose (2012) and Fiske (1987) highlight, these three sites in a sense leak into each other as a full textual reading, each site can also be read on its own. Here we focus on the site of the image itself as an entry point into reading resistance and well-being. As noted earlier, the actual image collection of our research to date is made up of photographs, posters, cellphilms, digital stories, bodymaps, storyboards, collages, and other forms of visual art. ${ }^{14}$ In our analysis we build on the idea of "working with a single photograph" (Moletsane \& Mitchell, 2007, p. 89) and the approaches of Batchen, Gidley, Miller, and Prosser (2014) in their compelling collection, Picturing Atrocity: Photography in Crisis. In that work, various authors offer essays on individual images from some of the most atrocious events in history, ranging from the iconography of famine, to the atrocity of severed hands in the Congo, 1904-1913.

Here we examine two posters selected from a collection of policy poster images produced by a group of Indigenous young women in South Africa: My body, your toy? No such luck! and Unsafe: In my space. At the time that they produced these images, they were first-year university students in a Faculty of Education. The students had participated in a variety of arts-based activities ranging from PhotoVoice and 
drawing, to cellphilm production. One of the follow-up activities they engaged in after the PhotoVoice work was to embark upon developing policy posters and action briefs (see De Lange, Mitchell, \& Moletsane, 2016; Mitchell, De Lange, \& Moletsane, in press b). Most of the 14 young women (all between the ages of 18 and 23) lived in the residences on campus, and so when they came together to identify safe and unsafe spaces, it is not surprising that the university campus itself was the focus of their images and dialogue, and also their policy posters and action briefs.

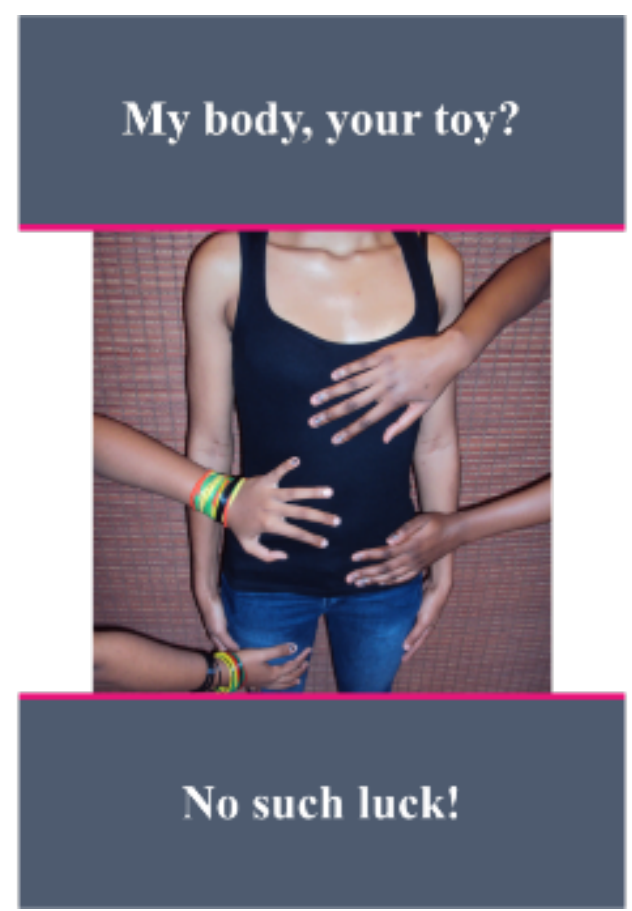

Fig. 4: My body, your toy? No such luck!

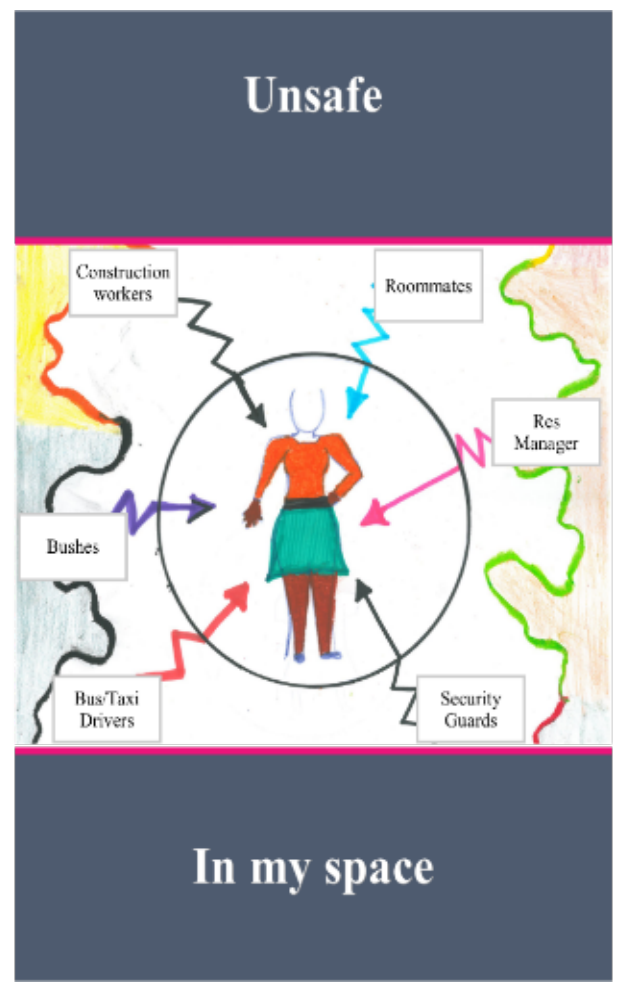

Fig. 5: Unsafe: In my space

Figure 4, My body, your toy? No such luck! addresses a critical feature of how young women felt about how they were objectified. The two sets of hands are presented as being very much separate from the young women in the picture. The positioning of the hands suggests the sexualizing of the young woman's body. The caption however, especially through the use of the question mark and No such luck!, offers a sharp contrast to the image. The punctuation used in the caption, a question mark and an exclamation mark, signal a clear "I don't think so" message.

Figure 5, Unsafe: In my space makes use of a drawing to represent resistance. The section of the caption, "In my space," is in and of itself poignant in relation to claiming a space, and we are reminded of the range of writings and images over the years produced by women artists and authors to claim space (see for example the work of South African artist Thembeka Qangule, a visual response to her experiences of constructed social and spatial constraints [Perryer, 2004], ${ }^{15}$ or the art exhibition called Claiming Space: Voices of Urban Aboriginal Youth, ${ }^{16}$ presented in UBC Museum of Anthropology in 2014). The image of 
the young woman is set against a map that suggests an all-encompassing sense of danger. The six unsafe spaces listed are daunting: bus/taxi drivers, bushes, construction workers, roommates, the residence manager, and security guards, and represent a multitude of places where young women do not feel safe. It is worth noting that one of their cellphilms deals with the theme of "sexually transmitted marks," highlighting the fact that they are also not safe in the classroom, where the possibilities for sexual harassment and transactional sex (an instructor will offer a higher grade for a course if the young women consent to sex) are great.

Both poster images carry with them the idea of picturing resistance (this is my body, this is my space), but also picturing as resistance since the poster genre they use is a genre that is typically a feature of public discourse (see Buckingham \& Sefton-Green, 1994; Mitchell \& Burkholder, 2015). The images in the posters are directed towards potential perpetrators, and, as such, offer up the theme of resistance in relation to audience. In the case of My body, your toy? No such luck! we have an association with intimate partner violence and the idea of countering a type of rape culture. Unsafe: In my space targets more generalized harassment coming from construction workers and security guards.

What is key about these two examples is their local appeal and the idea that policy dialogue can happen "on the ground" through the actions of a group of 14 young women. In this case "the ground" is at the level of the university itself and involving local actors such as the residence manager or dean of students. While this may seem far away from establishing a national policy on campus-based violence, it is this local activism, as Jessica Taft (2012) argues, that can be so important to bringing about change precisely because it is at a local level. While these may not look from the outside like dramatic examples of activism and resistance, the discourses contained within these policy posters suggest an ownership of the ideas and an intent to do something. It is worth noting that the young women, "Girls Leading Change" as they described themselves, have also gone on to produce a collection of written narratives, 14 Times a Woman: Indigenous Stories From the Heart (2016). Many of these narratives come out of the initial group work of cellphilming, PhotoVoice, and drawing, and, as Nokukhanya Ngcobo (2016) notes in her review of the collection, draw attention to the significance of personal expression and well-being.

\section{Discussion and Conclusion}

Through examples from the body of literature on activism, resistance, and the arts in relation to sexual violence and through examples from our fieldwork, we have argued in this article that integrating the idea of resistance and activism into frameworks on well-being seems to be particularly relevant to work with young people in school and in community contexts. We know that this requires much more research, acknowledging as Ballard and Ozer (2016) do, that to date, there is little research on the role of activism and resistance in relation to health and well-being of young people even though, as the authors point out, youth activism is associated with self-esteem, empowerment, and self-confidence. Interestingly, while we have various publications which offer broader perspectives on audience and spectatorship as can be seen in the work of James Elkins' Pictures and Tears: A History of People Who Have Cried in Front of Paintings (2001), Mitchell's What Do Pictures Want? The Lives and Loves of Images (2005), and Susan Sontag's 
Regarding the Pain of Others (2004), there is a dearth of data in the area of sexual violence on audience research and what the images might mean to those most implicated. This is an area that is being studied as part of the Networks for Change and Well-Being both in relation to interviews with other researchers engaged in youth-led participatory research and in relation to policy makers and community leaders (see Mitchell, De Lange, \& Moletsane, in press).

Reading the resistance images from our fieldwork against the powerful images of resistance and activism produced by various artists, we argue for aligning work with girls and young women in the area of wellbeing and work with participatory visual methods through the idea of resistance. We know that the social identities of young people are linked, among other things, to their health and wellness. However, notions of well-being and health are often regulated by policy makers, not always considering young people's social context and necessities. Health is presented as an individual responsibility, more than a social issue, tending to stereotype young people based not only on their age, but also on their gender, ethnic identity, or class position (Brown et al., 2013). However, while young people are the recipients of social policy, they are also active participants in the construction of their personal and social identities (Ballard \& Ozer, 2016). As Brown and colleagues (2013) highlight, young people are actively reshaping and resisting dominant discourses, including those related to health and well-being, by taking control over their own identities and reshaping social policies. Young people, like others, are likely to flourish in a climate of activism. Activists perceive their lives as more vital, happy, and fulfilled than non-activists. Activism is important for social justice and the development of youth (Ballard \& Ozer, 2016) and an inherently motivating activity that satisfies important psychological needs and a healthy functioning. As Klar and Kasser (2009) note, promoting positive personal development, activism—understood here as a political engagement to influence social change-is associated with higher levels of both personal and social well-

being. We conclude then that engagement through art, activism, and resistance can play a role in young girls and women's healthy development, resulting in personal empowerment and ideally, structural changes to resist stereotypical categorizations and identifications of race, gender, sexuality, and class. Considering the importance of studying the world from the standpoint of girls and young women both as knowers and as actors (Oakley, 1994), we go back to the fieldwork data where the young women articulated their resistance through captions such as "in my space" and "no such luck!", we get a sense of how the arts and visual practices might allow young people to flourish in difficult circumstances.

\section{Acknowledgments}

This work was supported through an International Development Research Centre (IDRC) grant (award number 107777-001) and a Social Sciences and Humanities Research Council of Canada (SSHRC) grant (award number 895-2013-3007). The views expressed in this paper are not necessarily those of the IDRC or SSHRC. We would like to acknowledge Naydene De Lange and Relebohile Moletsane for leading the data collection and preliminary analysis discussed in this paper. We also acknowledge Fatima Khan for her assistance in producing this manuscript. Finally, we would like to thank the participants for sharing their images. 


\section{Notes}

1. Fact Sheet: Violence Against Aboriginal Women: https://nwac.ca/wpcontent/uploads/2015/05/Fact_Sheet_Violence_Against_Aboriginal_Women.pdf

2. Truth and Reconciliation Commission of Canada website: http://www.trc.ca/ and The South African Truth and Reconciliation Commission: http://www.justice.gov.za/trc/

3. Human Rights Watch website: https://www.hrw.org/

4. United Nations website: http://www.un.org/en/index.html

5. National Inquiry website: http://www.mmiwg-ffada.ca

6. See http://www.gov.za/services/launch-national-council-against-gender-based-violence

7. The Chief Public Health Officer's Report on the State of Public Health in Canada, 2011: Youth and Young Adults - Life in Transition: http://www.phac-aspc.gc.ca/cphorsphc-respcacsp/2011/indexeng.php

8. See for example: https://www.pastemagazine.com/articles/2017/01/subway-therapy-art.html

9. The REDress Project: http://www.redressproject.org

10. Walking With Our Sisters: http://walkingwithoursisters.ca

11. The Faceless Dolls Project: https://www.nwac.ca/wpcontent/uploads/2015/05/2012_Building_on_the_Legacy_of_NWAC_Faceless_Doll_Project.pdf

12. Dirty Laundry: https://www.theguardian.com/world/2016/dec/02/dirty-laundry-washing-line-arthighlights-south-africas-epidemic

13. Loslappies: http://www.marieclaire.co.za/class-of-consent/artists-engaging-sexual-violence-terms

14. See: http://www.networks4change.org

15. Thembeka Qangule, a South African artist and lecturer at the College of Cape Town, uses her work to claim personal and social spaces. Through art, she intends to disrupt and transcend the boundaries that marginalization, oppression, and domination have set around her and her body.

16. Claiming Space: Voices of Urban Aboriginal Youth, curated by Pam Brown, presents contemporary art by young Indigenous artists from around the world that responds to their lived experiences as urban Aboriginal youth. The exhibition tour involved discussion about the missing and murdered Indigenous women in Canada, and the Idle No More movement. See: http://moa.ubc.ca/blog-nypclaimingspace/ 


\section{References}

Ballard, P. J., \& Ozer, E. J. (2016). The implications of youth activism for health and well-being. In J. Conner \& S. M. Rosen (Eds.), Contemporary youth activism: Advancing social justice in the United States (pp. 223-243). Santa Barbara, CA: Greenwood.

Banwari, M. (2011). Poverty, child sexual abuse and HIV in the Transkei region, South Africa. African Health Sciences, 11(3), 117-121. doi:10.4314/ahs.v11i3.70081

Batchen, G., Gidley, M., Miller, N. K., \& Prosser, J. (2014). Picturing atrocity: Photography in crisis. London, UK: Reaktion Books.

Bloustien, G. (2003). Girl making: A cross-cultural ethnography on the processes of growing up female. New York: Berghahn.

Bourassa, C., McKay-McNabb, K., \& Hampton, M. (2004). Racism, sexism and colonialism: The impact on the health of Aboriginal women in Canada. Canadian Woman Studies, 24(1), 23-29.

Brown, S., Shoveller, J., Chabot, C., \& LaMontagne, A. D. (2013). Risk, resistance and the neoliberal agenda: Young people, health and well-being in the UK, Canada and Australia. Health, Risk and Society, 15(4), 333-346. doi:10.1080/13698575.2013.796346

Buckingham, D. (2003). Media education: Literacy, learning and contemporary culture. Cambridge, UK: Polity Press.

Buckingham, D. (Ed.). (2007). Youth, identity and digital media. Cambridge, MA: MIT Press.

Buckingham, D., \& Sefton-Green, J. (1994). Cultural studies goes to school: Reading and teaching popular media. London, UK: Taylor \& Francis.

Carli, V. (2012). The city as a "space of opportunity": Urban Indigenous experiences and community safety partnerships. In D. Newhouse, K. FitzMaurice, T. McGuire-Adams, \& D. Jetté (Eds.), Well-being in the urban Aboriginal community: Fostering Biimaadiziwin, a National Research Conference on Urban Aboriginal peoples (pp. 1-21). Toronto: Thompson Educational Publishing, Inc.

Caron, C., Raby, R., Mitchell, C., Théwissen-LeBlanc, S., \& Prioletta, R. (2016). From concept to data: Sleuthing social change-orientated youth voice on YouTube. Journal of Youth Studies, 20(1), 47-62. doi:10.1080/13676261.2016.1184242

Carrington, V., \& Robinson, M. (Eds.). (2009). Digital literacies: Social learning and classroom practices. Los Angeles: Sage.

Clacherty, G. (2005). Refugee and returnee children in southern Africa: Perceptions and experiences of violence-A qualitative study of refugee and returnee children in UNHCR operations in Angola, South Africa, and Zambia [Report]. Pretoria, South Africa: UNHCR.

Clover, D. (2005). Sewing stories and acting activism: Women's leadership and learning through drama and craft. Ephemera: Theory \& Politics in Organization, 5(4), 629-642. Retrieved from http://www.ephemerajournal.org/sites/default/files/5-4clover.pdf

Clover, D. (2011). Successes and challenges of feminist arts-based participatory methodologies with homeless/street-involved women in Victoria. Action Research, 9(1) 12-26.

doi:10.1177/1476750310396950 
Crane, D. (2000). Fashion and its social agendas: Class, gender, and identity in clothing. Chicago: University of Chicago Press.

Crivello, G., Camfield, L., \& Woodhead, W. (2009). How can children tell us about their wellbeing? Exploring the potential of participatory research approaches within young lives. Social Indicators Research, 90(1), 51-72. doi:10.1007/s11205-008-9312-x

De Castell, S., \& Jenson, J. (2003). OP-ED: Serious play. Journal of Curriculum Studies, 35(6), 649-665. doi:10.1080/0022027032000145552

De Lange, N., Mitchell, C., \& Moletsane, R. (2015). Girl-led strategies to address campus safety: Creating action briefs for dialogue with policy makers. Agenda: Empowering Women for Gender Equity, 29(3), $118-127$.

De Lange, N., Moletsane, R., \& Mitchell, C. (2015). Seeing how it works: A visual essay about critical and transformative research in education. Perspectives in Education, 33(4), 151-176. Retrieved from http://hdl.handle.net/10520/EJC185864

Denov, M., Doucet, D., \& Kamara, A. (2012). Engaging war-affected youth through photography: Photovoice with former child soldiers in Sierra Leone. Intervention: The International Journal of Mental Health, Psychosocial Work and Counselling in Areas of Armed Conflict, 10(2), 117-131. doi:10.1097/WTF.0b013e328355ed82

Didkowsky, N., Ungar, M., \& Liebenberg, L. (2010). Using visual methods to capture embedded processes of resilience for youth across cultures and contexts. Journal of the Canadian Academy of Child and Adolescent Psychiatry, 19(1), 12-18.

Eaglewoman. A. (2016, August). Why the inquiry into missing, murdered indigenous women must engage all Canadians. The Globe and Mail. Retrieved from http://www.theglobeandmail.com/opinion/inquiryinto-missing-murdered-indigenous-women-must-engage-all-canadians/article31271844/

Elkins, J. (2001). Pictures and tears: A history of people who have cried in front of paintings. New York: Routledge.

Ezcurra Lucotti, M. (2016). The threads, trends and threats of the wedding dress: A collaborative, studiobased dissertation [Doctoral thesis]. Concordia University, Montreal, Canada.

Fiske, J. (1987). Television culture. London: Methuen.

Flicker, S., \& Danforth, J. (2012). Taking Action! Art and Aboriginal Youth Leadership for HIV Prevention. Retrieved from http://www.takingaction4youth.org/pdfs/Taking_Action_Government_Report.pdf

Flicker, S., Wilson, C., Native Youth Sexual Health Network., Prentice, C., Oliver, C., Jackson, R., et al. (in press). Stay strong, stay sexy, stay native: Storying, Indigenous youth, and HIV prevention activism. Action Research.

Flicker, S., Danforth, J., Konsmo, E., Wilson, C., Oliver, V., Jackson, R., et al. (2013). "Because we are Natives and we stand strong to our pride": Decolonizing HIV Prevention with Aboriginal Youth in Canada Using the Arts. Canadian Journal of Aboriginal Community-Based HIV/AIDS Research, 5, 4-24.

Girls Leading Change. (2016). 14 Times a Woman: Indigenous Stories from the Heart. Port Elizabeth: Nelson Mandela Metropolitan University. 
Gonick, M. (2016). Voices in longitude and latitude: Girlhood at the intersection of art and ethnography. In C. Mitchell \& C. Rentschler (Eds.), Girlhood and the politics of place (pp. 38-50). New York: Berghahn.

Gubrium, A. (2009). Digital storytelling: An emergent method for health promotion research and practice. Health Promotion and Practice, 10(2), 186-191. doi:10.1177/1524839909332600

Halseth, R. (2013). Aboriginal women in Canada: Gender, socio-economic determinants of health, and initiatives to close the wellness-gap. Prince George, BC: National Collaborating Centre for Aboriginal Health. Retrieved from http://www.ccnsanccah.ca/Publications/Lists/Publications/Attachments/77/AboriginalWomenCanada_Web_EN.pdf

Hill, K. (2013). The arts and individual wellbeing in Canada: Connections between cultural activities and health, volunteering, satisfaction with life, and other social indicators in 2010. Statistical Insights on the Arts, 11(2). Retrieved from http://www.hillstrategies.com/sites/default/files/Arts_well_being2010.pdf

Jenkins, H. (2006). Convergence culture: Where old and new media collide. New York: New York University Press.

Klar, M., \& Kasser, T. (2009). Some benefits of being an activist: Measuring activism and its role in psychological well-being. Political Psychology, 30(5), 755-777. doi:0.1111/j.1467-9221.2009.00724.x

Kovach, M. (2009). Indigenous methodologies: Characteristics, conversations and contexts. Toronto, ON: University of Toronto Press.

Leach, F., \& Mitchell, C. (Eds). (2006). Combating gender violence in and around schools. Stoke on Trent, UK: Trentham Books.

Liebenberg, L. (2009a). The visual image as discussion point: Increasing validity in boundary crossing research. Qualitative Research, 9(4), 441-467. doi:10.1177/1468794109337877

Liebenberg, L. (2009b). The use of image-based methods in research with youth. In L. Liebenberg \& M. Ungar (Eds.), Researching youth resilience (pp. 129-152). Toronto, ON: University of Toronto Press.

MacDonald, J. P., Ford, J., Willox, A. C., Mitchell, C., Konek Productions, My Word Storytelling and Digital Media Lab, \& Rigolet Inuit Community Government. (2015). Youth-led participatory video as a strategy to enhance Inuit youth adaptive capacities for dealing with climate change. Arctic Institute of North America, 68(4), 486-499. doi:10.14430/arctic4527

Mallan, K. (2009). Look at me! Look at me! Self-representation and self-exposure through online networks. Digital Culture and Education, 1(1), 51-66. Retrieved from

http://eprints.qut.edu.au/20920/1/Look_at_me_mallan_2009.pdf

Malone, K. (2008). Every experience matters: An evidence based research report on the role of learning outside the classroom for children's whole development from birth to eighteen years [Research report] Stoneleigh, UK: Farming and Countryside Education.

Mand, K. (2012). Giving children a 'voice': Arts-based participatory research activities and representation. The International Journal of Social Research Methodology, 15(2), 149-160.

Martin, M. (2003). HIV/AIDS in South Africa: Can the visual arts make a difference? In K. Kauffman \& D. Lindauer (Eds.), AIDS in South Africa: The social expression of a pandemic (pp. 120-135). New York: Palgrave. 
Mitchell, C. (2009). Geographies of danger: School toilets in sub-Saharan Africa. In O. Gershenson \& B. Penner (Eds.), Ladies and gents: Public toilets and gender (pp. 62-74). Philadelphia: Temple University Press.

Mitchell, C. (2011a). Doing visual research. New York: Sage.

Mitchell, C. (2011b). What's participation got to do with it? Visual methodologies in 'girl-method' to address gender based violence in the time of AIDS. Clobal Studies of Childhood, 1(1), 51-59. doi:10.2304/gsch.2011.1.1.51

Mitchell, C. (2012.) Putting people in the picture and keeping people in the picture: What's participation got to do with it. In M. Frackowiak, L. Olszewski, \& M. Rosin'ka (Eds.), Collaboratorium: A participatory space for social change (pp. 89-98). Poznan, Poland: Fundacja SPOT.

Mitchell, C., \& Burkholder, C. (2015). Literacies and research for social change. In K. Pahl \& J. Rowsell (Eds.), The Routledge handbook of literacy studies (pp. 649-662). New York. Routledge.

Mitchell, C., de Lange, N., \& Moletsane, R. (in press a). Girls and young women addressing sexual violence in South Africa: Gender activism in the making. In. E. Oinas (Ed.), What politics? Youth and political activism. Amsterdam, The Netherlands: Brill.

Mitchell, C, de Lange, N. \& Moletsane, R. (in press b). Participatory visual methodologies: Social change, community and policy. London: Sage.

Mitchell, C., Walsh, S., \& Moletsane, R. (2006). Speaking for ourselves: Visual arts-based and participatory methodologies for working with young people. In F. Leach \& C. Mitchell (Eds.), Combating gender violence in and around schools (pp. 103-111). Stoke on Trent, UK: Trentham.

Mitchell, W. T. (2005). What do pictures want?: The lives and loves of images. Chicago: University of Chicago Press.

Moletsane, R. (2011). Culture, nostalgia, and sexuality education in the age of AIDS in South Africa. In C. Mitchell, T. Strong-Wilson, K. Pithouse, \& S. Allnutt (Eds.), Memory and pedagogy (pp. 193-208). London, UK: Routledge.

Moletsane, R., De Lange, N., Mitchell, C., Stuart, J., Buthelezi, T., \& Taylor, M. (2007). Photo-voice as a tool for analysis and activism in response to HIV and AIDS stigmatization in a rural KwaZulu-Natal school. Journal of Child and Adolescent Mental Health, 19(1), 19-28. doi:10.2989/17280580709486632

Moletsane, R., \& Mitchell, C. (2007). On working with a single photograph. In N. De Lange, C. Mitchell, \& J. Stuart (Eds.), Putting people in the picture: Visual methodologies for social change (pp. 131-140). Amsterdam, The Netherlands: Sense.

Moletsane R, Mitchell, C., \& Lewin, T. (2010). A critical analysis of gender violence and inequality in and around schools in South Africa in the age of AIDS: Progress or retreat? Presented at the Engendering Empowerment: Education and Equality Conference, UNGEI Conference, Dakar, Senegal, 17-20 May 2010.

Moletsane, R., Mitchell, C., \& Lewin, T. (2015). Gender equity as policy in South Africa: Privileging the voices of women and girls through participatory visual methods. In J. Parkes (Ed.), Gender violence and violations: The educational challenge in poverty contexts (pp. 183-196). London, UK: Routledge. 
Moletsane, R., Mitchell, C., Smith, A., \& Chisholm, L. (2008). Methodologies for mapping a Southern African girlhood. Rotterdam, The Netherlands: Sense.

Morrison, C. (2010). Who do they think they are? Teenage girls and their avatars in spaces of social online communication. New York: Peter Lang.

Motsemme, N. (2007). 'Loving in the time of hopelessness': On township women's subjectivities in a time of HIV/AIDS. In N. Gasa (Ed.), Women in South African history: They remove boulders and cross rivers (pp. 369-398). Cape Town, South Africa: HRSC Press.

Networks4Change. (2017, March). Networks4Change Newsletter, 4.

Ngcobo, N. (2016). Their journey to triumphant activism: 14 young women speak out. Girlhood Studies: An Interdisciplinary Journal, 9(2), 101-106.

Oakley, A. (1994). Women and children first and last: Parallels and differences between children's and women's studies. In B. Mayall (Ed.), Children's childhoods: Observed and experienced (pp. 13-32). London, UK: Falmer Press.

Perryer, S. (2004). 10 years, 100 Artists: Art in a Democratic South Africa. Bell-Roberts Publishing in association with Stuik Publishers, Cape Town, South Africa.

Poletti, A. (2008). Intimate ephemera: Reading young lives in Australian zine culture. Carlton, Australia: Melbourne University Press.

Rose, G. (2012). Visual methodologies: An introduction to the interpretation of visual materials. London, UK: Sage.

Rose, G. (2014). On the relation between "visual research methods" and contemporary visual culture. The Sociological Review, 62(1), 24-46.

Seligman, M. E. P. (2011). Flourish: A visionary new understanding of happiness and well-being. New York: Simon \& Schuster.

Sontag, S. (2004). Regarding the pain of others. New York: Picador.

Stuart, J., \& Mitchell, C. (2013). Media and social change: Working within a "youth as knowledge producers" framework. In D. Lemish (Ed.), The Routledge international handbook of children, adolescents and media (pp. 359-365). New York: Routledge.

Taft, J. K. (2012). "The Rebel Girls of the Other Campaign: The EZLN and Teenage Activism in Mexico City." In Cultural Politics and Resistance in the 21st Century: Community Based Social Movements and Global Change in the Americas, edited by Clare Weber and Kara Dellacioppa. New York: Palgrave McMillan.

Tepper, S. J, Sisk, B., Johnson, R., Vanderwerp, L., Gale, G., \& Gao, M. (2014). Artful living: Examining the relationship between artistic practice and subjective wellbeing across three national surveys. Nashville, TN: The Curb Center for Art, Enterprise, and Public Policy at Vanderbilt University. Retrieved from http://www.giarts.org/sites/default/files/artful-living-relationship-artistic-practice-subjective-wellbeing.pdf

Teunissen, J. (2009). Fashion and art. In J. Brand \& J. Teunissen (Eds.), Fashion and imagination: About clothes and art (pp. 10-25). The Netherlands: ArtEZ Press. 
Theron, L. C., Liebenberg, L., \& Ungar, M. (Eds.). (2015). Youth resilience and culture: Commonalities and complexities. New York: Springer.

Treffry-Goatley, A. J., Wiebesiek, L., \& Moletsane, R. (2016). Using the visual to address gender-based violence in rural South Africa: Ethical considerations. LEARNing Landscapes, 10(1), 341-359. Retrieved from http://www.learninglandscapes.ca/images/documents/ll-no19/Ino19finallr.pdf - page=341

Treffry-Goatley, A. J., Wiebesiek, L., de Lange, N., \& Moletsane, R. (forthcoming). Technologies of nonviolence: Ethical participatory visual research with girls. Girlhood Studies: An Interdisciplinary Journal, $10(2)$.

White, M. (2015). Producing women: The Internet, traditional femininity, queerness, and creativity. New York: Routledge.

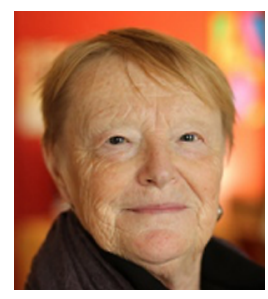

Claudia Mitchell, PhD, FRSC, is a James McGill Professor, McGill University, where she is the Director of the Institute of Human Development and Well-Being. She is also an Honorary Professor at the University of KwaZulu-Natal, in South Africa. Her research interests span work in schools with teachers and young people, particularly in the context of gender, HIV, and AIDS; girlhood studies; and participatory visual methodologies and community-based research. She is the author of numerous books on participatory visual methodologies and is the Editor-in-Chief of Girlhood Studies: An Interdisciplinary Journal.

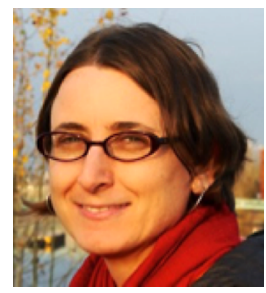

Maria Ezcurra, PhD in Art Education, is currently working in McGill's Institute for Human Development and Well-Being and as an Art-Mediator in the Faculty of Education. Maria is an educator and practicing artist. She has participated in numerous exhibitions and art projects in Canada and internationally. Her areas of research interest are arts-based research, participatory visual methods, collaborative art practices, feminist art education, dress and textiles, violence against women, and immigration. 